\title{
Representasi Budidaya Rumput Laut Dan Kain Rangrang Dalam Tari Gulma Penida
}

\author{
Ni Made Arshiniwati' I Wayan Mudra², Ni Luh Sustiawati ${ }^{3}$, \\ I Gusti Ngurah Sudibya ${ }^{4}$, Yanti Heriyawati ${ }^{5}$ \\ ${ }^{1}$ Program Studi Seni Tari FSP Institut Seni Indonesia Denpasar. \\ ${ }^{2}$ Program Studi Desain Program Magister Institut Seni Indonesia Denpasar. \\ ${ }^{3}$ Program Studi Pendidikan Seni Pertunjukan FSP Institut Seni Indonesia Denpasar. \\ ${ }^{4}$ Program Studi Seni Tari FSP Institut Seni Indonesia Denpasar. \\ ${ }^{5}$ Program Studi Penciptaan dan Pengkajian Seni Pascasarjana Institut Seni Budaya Indonesia Bandung.
}

1arshiniwati@gmail.com

Nusa Penida merupakan kecamatan di dareah pesisir di Kabupaten Klungkung Bali yang banyak dikunjungi wisatawan nasional maupun internasional dan terkenal dengan mata pencahariannya berupa budi daya rumput laut dan kerajinan kain rangrang. Penelitian ini bertujuan menciptakan sebuah tarian yang mengangkat potensi SDA rumput laut dan kerajinan kain rangrang di Desa Nusa Penida Kecamatan Klungkung Kabupaten Klungkung Bali sebagai upaya pengembangan atraksi wisata di desa tersebut. Teknik pengumpulan data dilakukan dengan observasi, wawancara dan dokumentasi. Metode penciptaan tari ini dilakukan melaui tahapan eksplorasi, improvisasi, dan pembentukan. Dalam proses penciptaannya melibatkan publik sebagai penilai untuk penyempurnaan karya yang dilakukan melalui FGD dan pementasan. Hasil penelitian menunjukkan tercipta sebuah tari pesisir yang berdurasi 8.14 menit, diberi judul Tari Gulma Penida. Tarian ini dibawakan oleh 4 orang penari laki-laki dan perempuan sebagai penggambaran petani rumput laut di Desa Nusa Penida. Pada tarian ini ditampilkan kisah keseharian petani rumput laut dalam melakoni aktifitasnya mulai dari bangun pagi, pergi kelaut, menanam, merawat, memanen, dan membawa pulang hasil panennya dan menikmati kegembiraan atas berkah yang dilimpahkan oleh Tuhan Yang Maha Kuasa. Kain rangrang dalam penciptaan tari ini digunakan sebagai kostum untuk menggambarkan potensi sumber daya yang ada di Nusa Penida.

Kata kunci: tari Gulma Penida, rumput laut, kain rangrang.

\section{Representation of Cultivation Seaweed and Rangrang Cloth in Gulma Penida Dance}

Nusa Penida was a sub-district the coastal area of Klungkung Regency, Bali, which visited by many national and international tourists and famous for cultivating seaweed and rangrang cloth handicrafts. This research aims to create a dance that raises the potential of seaweed natural resources and rangrang cloth handicrafts in the village of Nusa Penida, Klungkung District, Klungkung Regency, Bali, as an effort the develop tourism. The data collection techniques by observation, interviews and documentation. This dance creation method carried out by exploration, improvisation, and formation stages. The process of its creation, it involves the public as an appraiser for improvement the work carried out through FGDs and performances. The results showed that a coastal dance with a duration 8.14 minutes created, entitled Gulma Penida Dance. This dance performed by 4 male and female dancers as a depiction of seaweed farmers in Nusa Penida Village. In this dance, it describes the daily activities of seaweed farmers, starting from getting up early, going to the sea, planting, caring for, harvesting, and bringing their crops home and rejoicing over the blessings bestowed by God. Rangrang cloth in the creation of this dance was used as a costume to describe the potential resources that exist in Nusa Penida.

Keywords: Gulma Penida dance, cultivation seaweed, rangrang cloth.

Proses Review : 1 - 20 Mei 2021, Dinyatakan Lolos: 31 Mei 2021 


\section{PENDAHULUAN}

Nusa Penida merupakan wilayah kecamatan di Kabupaten Klungkung terdiri dari Pulau Nusa Lembongan, Pulau Nusa Ceningan, dan Pulau Nusa Penida. Pulau Nusa Penida terletak di sebelah tenggara Bali dan dapat dikunjungi melalui penyebrangan dari Pantai Sanur dan pelabuhan Tri Buana Kusamba di Klungkung. Nusa Penida cukup dikenal oleh wisatawan nusantara maupun wisatawan internasional. Hal ini bisa dilihat dari jumlah kunjungan wisatawan ke tempat ini masih tetap ada walaupun pada masa pandemi covid-19. Dinas Pariwisata Klungkung pada Balipost.com, 18 Maret 2020 menyebutkan jumlah kunjungan wisatawan sepanjang Januari 2020 sebanyak 56.425 orang, dan menurun setelah pandemi Covid-19 Februari 2020 sampai 50\% menjadi 22.031 orang.

Nusa Penida juga terkenal dengan budidaya rumput laut yang ditekuni oleh masyarakatnya terutama yang ada di Pulau Nusa Lembongan. Pulau Nusa Lembongan memiliki budidaya rumput laut yang sudah ditekuni sejak lama. Menurut cerita masyarakat setempat budidaya rumput laut khususnya di Desa Lembongan dipelopori oleh I Made Kawijaya (Pan Tarsin) almarhum 2008. Kawijaya pernah mendapatkan penghargaan dari Kementerian Menteri Negara Kependudukan dan Lingkungan Hidup 5 Juni 1986 dan penghargaan Satya Lancana Pembangunan dari Presiden Megawati Sukarnoputri 2003 terkait dengan pengabdiannya terhadap budidaya rumput laut ini. Dengan majunya kepariwisataan di Nusa Penida juga berimbas pada penduduk di Desa Lembongan, yaitu kegiatan budidaya pertanian rumput laut mulai tergeser tidak lagi merupakan pekerjaan utama masyarakat pesisir Desa Lembongan (Pradnyana, 2019). Namun karena pekerjaan pada bidang pariwisata berkurang pada masa pandemi Covid-19 yang melanda Indonesia, masyarakat setempat kembali menekuni budidaya rumput laut. Hal tersebut dijelaskan I Wayan Suarbawa, S.S. (48 tahun), diwawancarai 10 Agustus 2020 di Desa Lembongan.

Nusa Penida juga dikenal dengan potensi kerajinan kain tenun rangrang yang ditekuni oleh penduduk di Desa Karang Ampel. Penduduk setempat meyakini kerajinan kain tenun ini sebagai kain tenun leluhur warga Nusa Penida yang telah dimanfaatkan sebagai perlengkapan upacara keagamaan. Tenun rangrang memiliki ciri khusus yaitu pada lembaran kain tenun tersebut terdapat ruangruang kecil berlubang. Pewarnaan kain rangrang ini menggunakan bahan kimia yang dapat dibeli di toko-toko atau bahan dari bahan alami terbuat dari daun, buah dan akar-akaran tertentu (Sukerti, 2016).

Berdasarkan pertimbangan potensi Nusa Penida yang dijelaskan di atas, maka kami tim peneliti dari Institut Seni Indonesia Denpasar bekerjasama dengan Institut Seni Budaya Bandung dalam pendanaannya, melakukan penelitian dan penciptaan yang luarannya dalam bentuk hasil penciptaan tari yang diberi judul "Tari Gulma Penida". Budidaya rumput laut merupakan sebuah fenomena yang dijadikan ide dan gagasan dalam penciptaan sebuah karya seni. Hampir semua penciptaan seni berawal dari suatu ide dan gagasan yang dijadikan fenomena dalam menciptakan karya. Gagasan bermula dari pengamatan terhadap suatu objek, dalam hal ini objek budidaya rumput laut, kemudian direnungkan dalam-dalam hingga dicapai sebuah perasaan simpati dan akhirnya lebur dengannya menjadi sebuah bentuk empati (Yusril, 2018: 104-113).

Gulma dikenal sebagai spesies tumbuhan yang berasosiasi dengan tanaman budidaya dan beradaptasi pada habitat buatan manusia. Gulma mengganggu manusia dengan intensitas gangguan beragam dan tertentu (Moenandir, 2010: 1). Pada Wikivedia disebutkan gulma laut, ganggang laut, atau rumput laut merupakan salah satu sumber daya hayati yang terdapat di wilayah pesisir dan laut. Istilah "rumput laut" adalah rancu secara botani karena dipakai untuk dua kelompok «tumbuhan» yang berbeda. Dalam bahasa Indonesia, istilah rumput laut dipakai untuk menyebut gulma laut dan lamun. Rumput laut atau seaweeds sangat populer dalam dunia perdagangan, dalam ilmu pengetahuan dikenal sebagai alga/algae. Alga atau ganggang terdiri atas empat kelas yaitu Rhodophyceae (ganggang merah), Phaeophyceae (ganggang coklat), Cholorophyceae (ganggang hijau), dan Cyanophyceae (ganggang hijau-biru) (Kadi et al., 1988, dalam Priono, 2016: 1). Istilah "gulma" inilah yang menjadi pilihan pencipta untuk menamai ciptaan tari yang berbasis pada budidaya rumput laut di Nusa Pendia. Pertimbangannya walaupun dianggap tumbuhan mengganggu, tetapi tumbuhan ini mampu menghidupi petani rumput laut yang ada di Nusa Penida.

Penciptaan tari ini merupakan upaya pengenalan budaya pesisir kemaritiman Nusantara di Wilayah Pulau Bali yang diharapkan bisa memperkaya atraksi wisata yang sudah ada selama ini di Nusa Penida. Di samping itu penciptaan tari ini berupya mendukung program Pemerintah Daerah dan masyarakat mengembangkan destinasi wisata di Nusa Penida secara fisik maupun non fisik untuk membuat kepariwisataan di daerah ini semakin maju. Penggalian seni yang mendukung kepariwisataan di Nusa Penida terus digalakkan dan dikembangkan dengan tetap mempertimbangkan kelestarian lingkungan masih tetap terjaga. Damayanti (2017) dalam penelitian di Nusa Penida menyebutkan strategi pengembangan pariwisata diantaranya dapat dilakukan dengan penataan dan mempertahankan kelestarian lingkungan serta melibatkan masyarakat dalam pengembangan pariwisata.

Seni tari yang telah ada selama ini di Nusa Penida Bali di antaranya: tari baris jangkang, baris gede, tari renteng, tari gandrung, tari jejangeran dan lain-lain. Tari Baris Jangkang termasuk tarian sakral yang terdapat di Desa Pejukutan Kecamatan Nusa Penida Klungkung. Tarian ini ditarikan 
umumnya 9 orang laki-laki dan harus ganjil, dipentaskan secara rutin di Pura Desa setempat dan juga dipentaskan di lingkungan rumah saat diadakan upacara manusa yadnya. Pementasan di lingkungan rumah biasanya untuk naur sesangi yaitu ritual membayar kaul (Kemendikbud Dirjen Kebudayaan, 2015). Disamping itu di Nusa Penida juga terdapat tari baris gede (Budiarsa, 2020). Tari renteng juga terdapat di Desa Saren, Nusa Penida, merupakan tari sakral ditarikan secara massal oleh sekelompok wanita dewasa berjumlah ganjil. Gerak, busana, dan iringan musik tari ini sangat sederhana dan ditarikan secara berulang-ulang (Indrawan, 2021). Di Nusa Penida juga terdapat tari gandrung tepatnya di Desa Batukandik, ditarikan oleh dua orang laki-laki yang belum beranjak dewasa. Tari gandrung ini dipentaskan setiap 6 bulan sekali pada setiap upacara ngusabha di Pura Puseh Desa Batukandik, yaitu pada Rahinan Buda Cemeng Kelawu (Pramana, 2014). Dari penelusuran dokumen-dokumen ini, belum ada yang menciptakan karya tari yang bersumber dari potensi kekayaan budidaya rumput laut yang ada Nusa Penida khususnya di Pulau Nusa Lembongan. Dengan demikian penciptaan "Tari Gulma Penida" merupakan ciptaan baru yang mengangkat potensi sumber daya rumput laut.

\section{METODE PENELITIAN}

PenelitianpenciptaankaryatariGulmaPenidamenggunakan motode penciptaan Alma M. Hawkins (Hadi, 1990). Pada buku tersebut diuraikan tiga tahapan perkembangan kreatif yaitu: eksplorasi (berfikir, berimajinasi, merasakan dan merespon); improvisasi (memberikan kesempatan yang lebih besar kepada imajinasi untuk melahirkan bentukbentuk yang baru); pembentukan (membuat komposisi tari untuk memberi bentuk terhadap sesuatu yang telah ditemukan). Teknik pengumpulan data dilakukan dengan teknik observasi, wawancara, dan dokumentasi. Proses pengumpulan data ini merupakan tahap eksplorasi dari penciptaan ini, yaitu tahap pencipta berhubungan dengan alam dan lingkungan sosial masyarakat sebagai objek penciptaan. Kemudian dilanjutkan dengan proses improvisasi yaitu proses menumbuhkan daya kreatif dan inovatif pencipta, mengasah daya cipta, daya hayal dan keterampilan bermain di atas panggung (Yusril, 2018: 104-113). Tahap selanjutnya adalah tahap pembentukan tari. Penyempurnaan karya hasil penciptaan dilakukan melalui data hasil proses focus group discussion (FGD) dan proses uji publik.

\section{HASIL DAN PEMBAHASAN}

Hasil penelitian dan penciptaan ini telah mengahasilkan sebuah karya tari yang diberi judul "Tari Gulma Penida". Penciptaan karya ini dilakukan melalui beberapa tahapan mengacu pada teori Alma M. Hawkins yang disampaikan di atas. Pada tahap eksplorasi tim peneliti melakukan observasi langsung ke Pulau Nusa Lembongan mengamati aktifitas petani rumput laut pada pagi hari mulai dari menanam, memanen, dan mengolah pasca panen seperti memilah dan menjemur. Pada observasi juga dilakukan pengumpulan data dalam bentuk foto, video, dan dokumen hasil wawancara. Data yang terkumpul kemudian dilakukan reduksi data untuk memilah data yang terpakai dan tidak terpakai.

Aktivitas petani dalam bentuk gerakan-gerakan tangan dan tubuh pada budidaya rumput laut menjadi objek utama yang diolah dan dipindahkan ke dalam bentuk tarian yang dipilih secara selektif. Pengamatan secara teliti dan detail terhadap objek aktivitas petani rumput laut saat di laut, untuk memperoleh data yang tepat untuk proses perancangan tari selanjutnya. Setelah data terkumpul data yang terpilih, kemudian dilakukan analisis data untuk selanjutnya perancangan konsep tari dalam bentuk deskripsi. Kemudian konsep tersebut diterjemahkan atau dituangkan dalam bentuk gerak tari oleh tim peneliti bidang tari melalui penari yang terpilih. Tarian yang telah terbentuk melalui beberapa kali proses latihan, kemudian dilakukan penilaian melaui FGD (focus group discussion) dan uji publik melalui pementasan kepada masyarakat yang lebih luas. Kegiatan penilaian ini tujuannya untuk memperoleh respon dari penilai narasumber FGD dan masyarakat untuk penyempurnaan karya. Kemudian dilakukan penyempurnaan karya berdasarkan data yang diperoeh dari uji publik dan selanjutnya dilakukan perekaman terhadap hasil yang telah disempurnakan. Alur penciptaan tari Gulma Penida di atas mengikuti alur seperti bagan berikut.

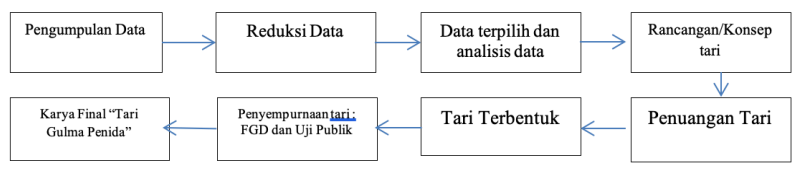

Gambar 1. Bagan Alur Penciptaan Tari Gulma Penida.

Tari Gulma penida menggambarkan aktifitas petani rumput laut dalam bentuk abstraksi gerakan-gerakan tari yang diperoleh dari pengamatan langsung terhadap kegiatan petani rumput laut di Desa Lembongan Nusa Penida. Gerakan-gerakan abstraksi tersebut kemudian disatukan menjadi satu bentuk tarian utuh yang digarap bernuansa Bali, dicirikan dengan penggunaan instrumen gambelan Bali. Objek aktifitas budidaya rumput laut yang menjadi inspirasi dalam penciptaan tari ini adalah ngepik (memetik atau membelah), negul (mengikat), nyemuh (menjemur), ngedeng (menarik), dan mentang (membentang), negen (memanggul), dan ngorot (membersihkan tali setelah panen).

Ragam gerak Tari Gulma Penida ini dapat dijelaskan dalam beberapa bagian seperti berikut.

Bagian Pertama, tarian ini menggambarkan petani rumput laut yang bersiap-siap untuk bekerja.

Ragam Gerak Penari Putri. Nyerigsig kanan dan kiri 


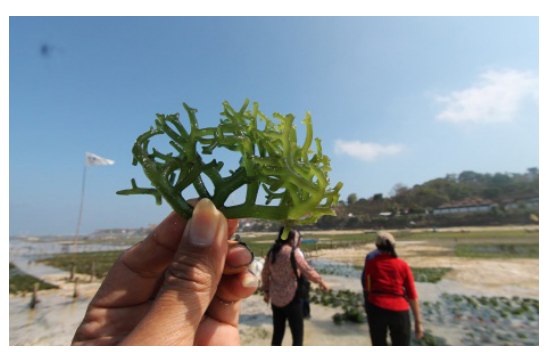

Gambar 2. Salah satu jenis rumput laut. (Sumber: Dok Tim Peneliti, 2020)

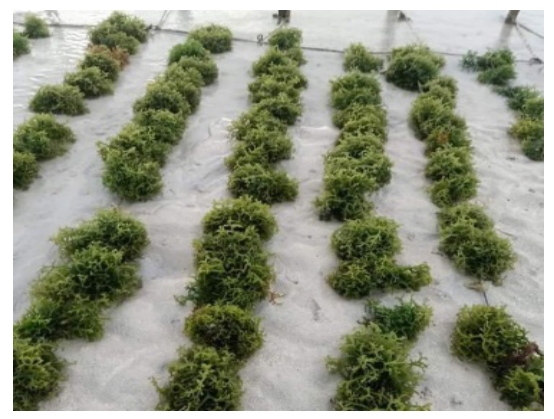

Gambar 5. Bibit rumput laut setelah dibentangkan beberapa hari dan siap dipanen. (Sumber: Dok Tim Peneliti, 2020.)

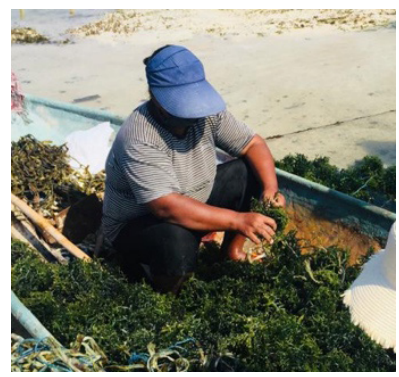

Gambar 8. Ngeles tali (membuka ikatan). (Sumber: Dok Tim Peneliti, 2020.)

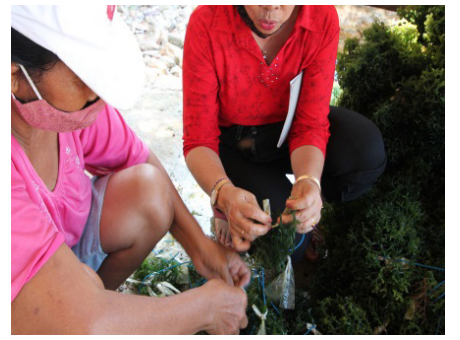

Gambar 3. Proses mengikat (negul) rumput laut sebagai bibit dengan tali plastik. (Sumber: Dok Tim Peneliti, 2020.)

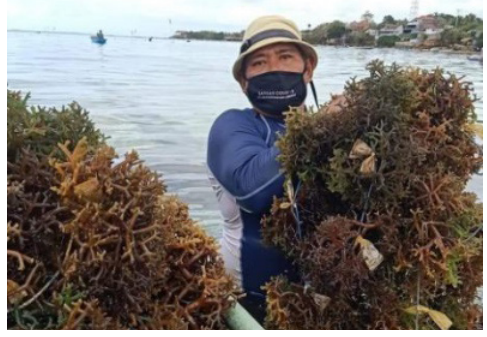

Gambar 6. Memanen rumput laut (Sumber: Dok Tim Peneliti, 2020.)

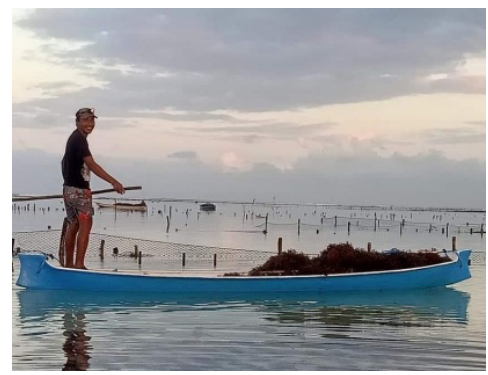

Gambar 9. Membawa hasil panen dengan perahu. (Sumber: Dok Tim Peneliti,

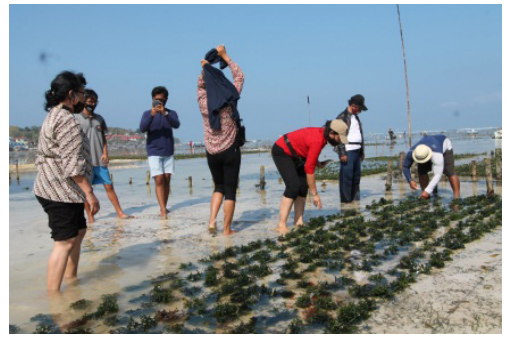

Gambar 4. Membentangkan (mentang) bibit rumput laut pada lahan

(Sumber: Dok Tim Peneliti, 2020.)

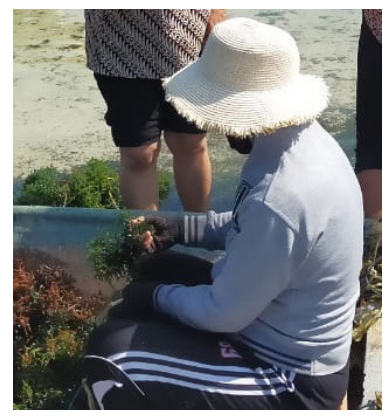

Gambar 7. Ngepik (memetik). (Sumber: Dok Tim Peneliti, 2020.)

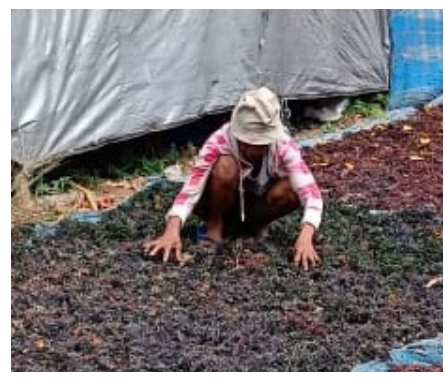

Gambar 10. Nyemuh (menjemur). (Sumber: Dok Tim Peneliti, 2020.) 2020.)

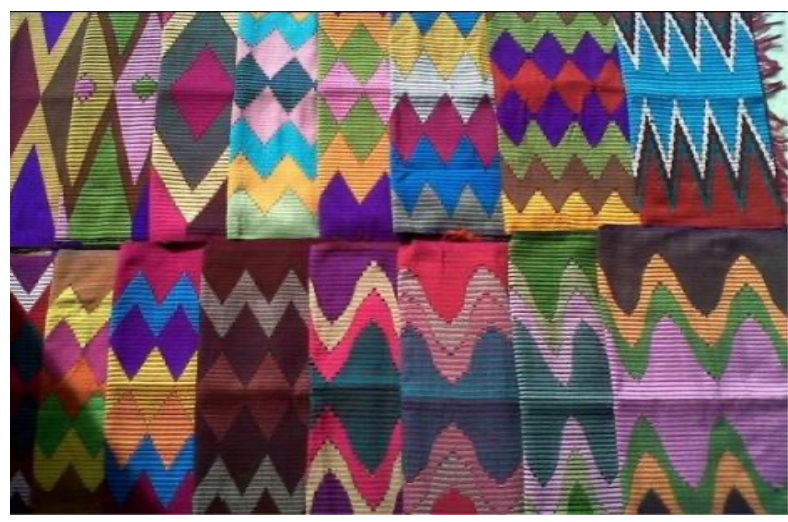

Gambar 11. Motif kain Rangrang khas Nusa Penida.

(Sumber: Dok Tim Peneliti, 2020.) 

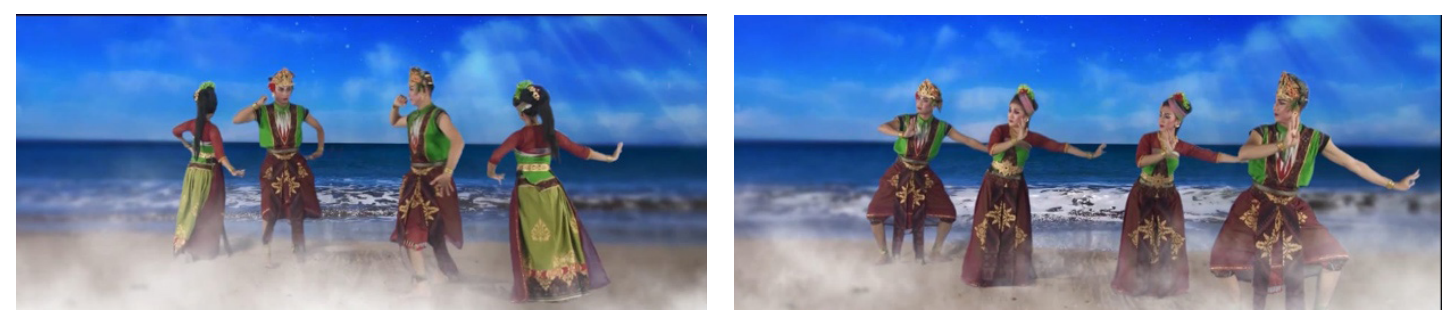

Gambar 12. Penggambaran petani rumput laut yang bersiap-siap untuk bekerja. Sumber: Dukumen Tim Peneliti, 2021.
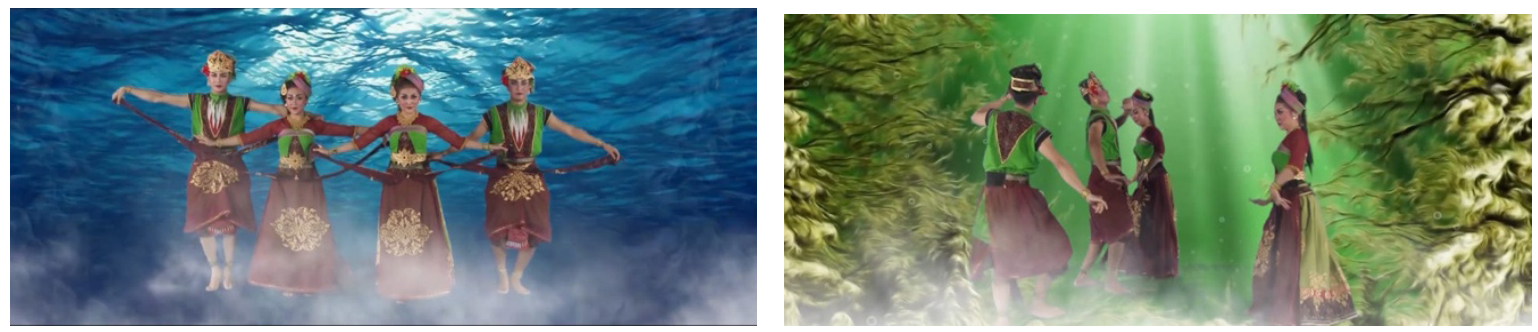

Gambar 13. Penggambaran aktivitas petani rumput laut yang sedang bekerja. Sumber: Dukumen Tim Peneliti, 2021.

dengan arah berlawanan, posisi agem pokok, berputar, nyerigsig mundur, nyalud, nanjek, jalan nyrigsig kedepan, piles agem kanan, kipek, ulap-ulap, rebah ngelung kiri, piles kanan gerakan tangan bergetar (simbul rumput laut), angget kiri, rebah ngelung kanan, gerakan ngepik dua kali, berputar ke kiri, tangan ngukel, membentang, agem, nyregseg posisi diagonal, nyalud, ngagem, rebah ngelung kanan, rebah ngelung kiri, ngangget kanan, rebah ngelung kiri, berputar dengan laki-laki.

Ragam Gerak Penari Putra. Pada bagian pertama ini, gerakan penari putra diawali dengan gerakan nyeregseg dari sisi panggung sebelah kanan dan kiri panggung yang arahnya menuju panggung bagian tengah mendekati posisi penari putri. Pada gerakan tersebut tangan kanan penari putra berada di bahu kanan, seperti penggambaran seorang petani rumput laut memikul peralatan untuk melakukan budi daya rumput laut, sedangkan tangan kiri berada di bawah yang sejajar dengan pinggul yang menggambarkan hal yang sama. Selanjutnya penari putra melakukan transisi berputar ke depan lalu melakukan gerakan kaki kiri yang disilang kearah bagian belakang dan dialjutkan dengan badan yang diputar ke arah kiri menuju ke posisi kebelakang penari putri. Dilanjutkan gerakan rampak bersama penari putri dengan posisi penari agem kanan yang tangan kanan dan kiri penari putra tetap sejajar dengan bahu dan pinggang yang di sertai gerakan nyeledet kearah kanan pada bagian akhir gerakan ini. Setelah selesai gerakan nyeledet, dilanjutkan dengan gerakan ulap-ulap yang disertai dengan ekspresi sedih penggambaran keterpurukan rakyat yang terkena misibah. Gerakan kemudian dilanjukan dengan gerakan terjatuh kearah sebelah kiri dengan tumpuan lutut kaki kanan, dan gerakan ulap-ulap kembali dilakukan dengan berlawanan arah dengan posisi tubuh rendah yang dilanjutkan dengan gerakan ngiket, dan ngepik dengan ekspresi sedih.

\section{Bagian kedua, tarian ini menggambarkan aktivitas} petani rumput laut yang sedang bekerja.

Ragam Gerak Penari Putri. Posisi hadap belakang, agem rebah (berlawanan kanan dan kiri) memegang selendang, putar agem rendah, ngepik, ngukel, negul, membentang (dilakukan dengan tempo cepat dan patah-patah ) kipek, nyrigsig ke posisi depan, ulap-ulap, ngelung rebah kiri dan kanan, agem kanan, berputar hadap-hadapan, ulapulap kanan, jalan nyrigsig berputar, jalan nayung sembelan kali langkah, gerakan memegang selendang membentang dan ngedeng, nyrigsig, membentang dan ngedeng, jalan nayung memegang kamen, berhadap-hadapan dengan pasangan, ulap-ulap, membentang memegang selendang digerakan perlahan naik turun nyregreg rendah, membentang membentuk perahu, ngelo kanan, ngelo kiri. Ragam Gerak Penari Putra. Penari putra pada bagian kedua ini terdapat transisi pola lantai dengan melakukan gerakan komunikasi dengan penari putra dan putri hingga pola lantai terbentuk diagonal. Penari selanjutnya melakukan gerakan menunjuk kearah pojok kanan dan melakukan gerakan ulap-ulap dengan satu tangan yang dilanjutkan dengan gerakan malpal mencari pola lantai selanjutnya. Setelah itu kembali melakukan interaksi dengan penari putri dengan ulap-ulap yang disertai dengan gerakan kepala yaitu ngotag dan gerakan tangan ngedeng kearah penari putri. Lalu melakukan transisi dengan gerakan kaki nyeregseg dengan membentangkan selandang hingga membentuk pola lantai horizontal, lalu penari melakukan gerakan kaki nyeregseg dengan level tinggi dan rendah 

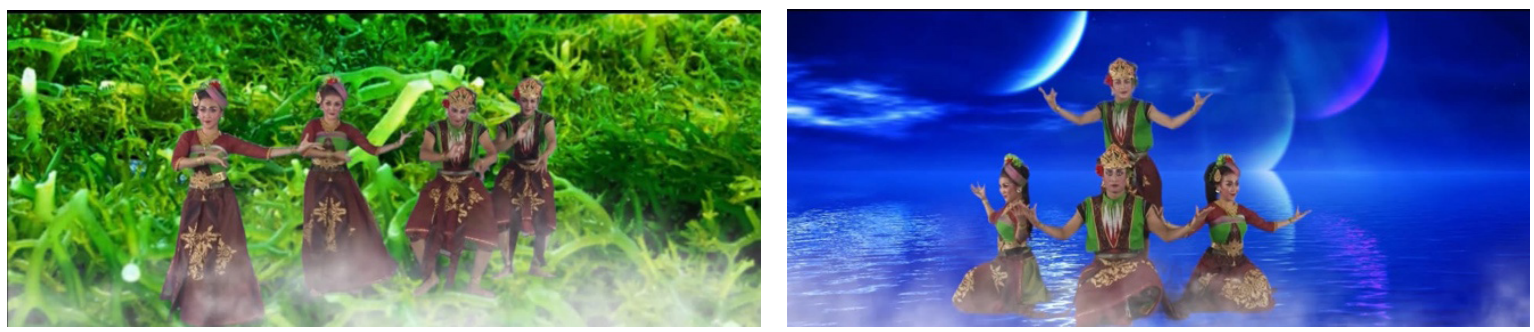

Gambar 14. Penggambaran beberapa gerak memanen hasil rumput laut. (Sumber: Dukumen Tim Peneliti, 2021.)
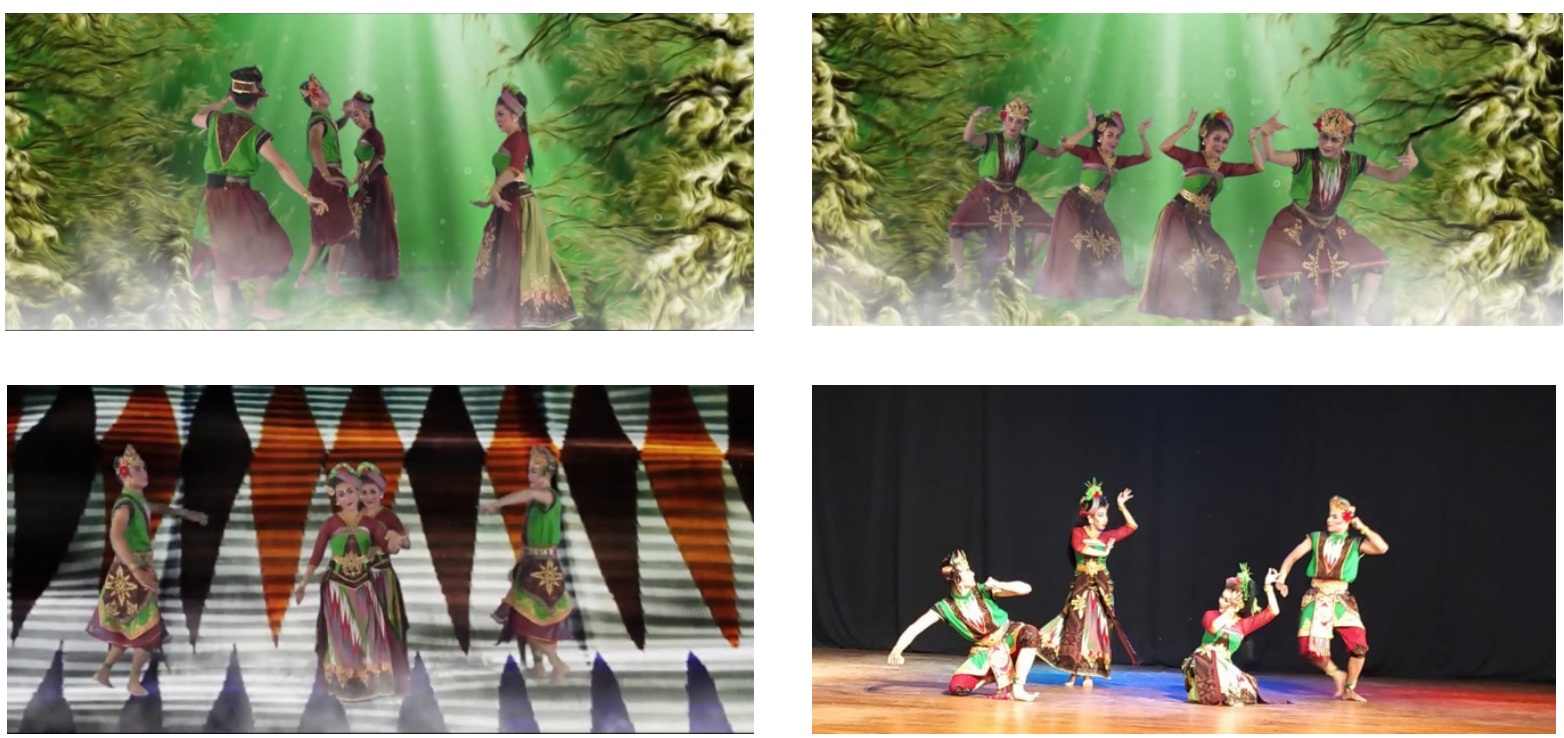

Gambar 15. Penggambaran kegembiraan petani rumput laut,

saat selesai memanen dan kembali pulang. (Sumber: Dukumen Tim Peneliti, 2021.)

secara bergantian, dan gerakan tangan bergerak seperti gerakan ombak yang ada di laut.

Bagian ketiga, tarian ini menggambarkan beberapa gerak memanen hasil rumput laut.

Ragam Gerak Penari Putri. Menggetarkan tangan dua kali sebagai abstraksi rumput laut, mengambil selendang, lalu berputar melingkar dan hadap ke belakang. Berputar hadap-kedepan, penari perempuan melakukan gerak ngepik sambil berjalan ke depan pojok kanan, gerakan nyemuh putar kanan, gerakan ngedeng, gerakan nyemuh putar kiri, gerakan memanen rumput laut dengan posisi level berbeda dengan penari satunya, mengganti posisi rok yang berisi wellcro dengan cara mengimprovisasi dengan tarian dan membersihkan keringat.

Ragam Gerak Penari Putra. Kedua tangan membentang/ mentang, dan kedua jari tangan digetarkan untuk sebagi simbol dari rumput laut. Gerakan ini dilakukan dengan berpindah komposisi atau bergeser dengan menggunakan gerak kaki cancer, karena salah satu dari penari cowok menyimbolkan seseorang nelayan yang sedang menarik rumput laut. Menyimbolkan gerak yang sedang menjemur rumput laut (nyemuh), memetik (ngepik) membeberkan (nyemuh), dan mematok. Disela-sela gerak ini kedua penari mengubah kostum untuk mempersiapkan bagian terakhir.

Bagian kempat, tarian ini menggambarkan kegembiraan petani rumput laut saat selesai memanen dan kembali pulang.

Ragam Gerak Penari Putri dan Putra. Ragam gerak perempuan dan laki-laki: ulap-ulap ke arah penari lakilaki, mencari penari laki, lalu menari berpasangan. Gerak ngepik dengan pola lantai berputar bersama penari laki dan perempuan. Gerak nyemuh dengan berputar berpasangan, gerakan ngedeng dilakukan bersama $4 \mathrm{x}$, berputar berhadapan dengan pasangan satunya lagi, metindaktindak dengan pola lantai zig-zag dan berputar dengan pola lantai air mancur membentuk posisi vertikal, lalu pose dengan dua gerakan dan level, lalu berputar air mancur, bertukar posisi dan membentuk posisi horizontal, gerakan berputar, ulap-ulap, tangan sikap parama santih di bagian kanan/kiri sebagai simbol rasa syukur, lalu bertemu dengan pasangan, dan penari ke luar dari panggung sebagai bentuk akhir tarian sudah selesai. 
Dari uaraian di atas dapat dijelaskan bahwa tari Gulma Penida merepresentasikan budi daya rumput laut di Nusa Penida yang ditransformasikan melalui gerak-gerak abstrak yang mengandung unsur dramatis. Berbagai suasana ditunjukkan oleh penari, baik melalui ekspresi sedih, ekspresi semangat, maupun ekspresi gembira dan bahagia. Sedangkan kain rangrang yang digunakan untuk kostum penari merepresentasikan produk masyarakat Nusa Penida yang ditenun dan dijadikan ciri khas Nusa Penida. Karya ini mampu mengungkapkan tema melalui gerak, sangat bernilai bagi penciptanya, mampu berkomunikasi kepada penonton, penari dan pendukung karawitan. Penataan busana juga memiliki keterampilan baik dalam mewujudkan karya ini, serta tersedianya peralatan teknis sebagai pendukung proses penciptaaanya. Proses kreatif penciptaan tari Gulma Penida selain mengadopsi dan mengembangkan gerak dari aktivitas budidaya rumput laut di pulau Nusa Lembongan, tetap memperhatikan kebutuhan garap atau koreografi seperti ritme, dinamika, ekspresi, desain kelompok, maupun kualitas gerak berupa gerak perkusif, gerak mengalir, gerak mengalun, gerak terpecah, maupun gerak patah. Kebutuhan garap ini dielaborasikan dengan baik agar penampilan karya memiliki nilai estetika, etika dan logika. Penciptaan tari Gulma Penida ini diharapkan mampu memperkaya jenisjenis tarian yang sudah ada sebelumnya di Nusa Penida dan juga dapat disuguhkan kepada wisatawan yang berkunjung ke Nusa Penida sebagai hiburan. Disamping itu penciptaan ini juga merupakan upaya pelestarian budidaya rumput laut dari sisi penyebarluasan informasi kepada masyarakat luas.

\section{SIMPULAN}

Aktivitas budidaya rumput laut di Nusa Penida Bali khususnya di Desa Nusa Lembongan merupakan potensi yang sudah lama dilakukan oleh masyarakat setempat. Budidaya ini mengalami pasang surut dalam perjalanannya dari waktu ke waktu. Pada saat kondisi kepariwisataan di Nusa Penida sedang baik, maka kegiatan budidaya rumput laut ini kurang diminati dan menjadi pekerjaan sambilan masyarakat, sebaliknya pada saat kondisi kepariwisataan sedang kurang baik, budidaya rumput laut ini kembali menjadi pilihan msyarakat untuk beraktivitas. Aktivitas budidaya rumput laut dan potensi kain rangrang di Nusa Penida merupakan sumber daya pilihan yang dijadikan objek inspirasi dalam menciptakan sebuah karya seni tari yang diberi nama Tari Gulma Penida.

Karya ini merupakan representasi dari kehidupan petani rumput laut di Nusa Penida mulai dari turun persiapan, turun kelaut, menanam, memanen, dan sampai menjemur hasil setelah di daratan. Kain rangrang dijadikan bagian dari pembuatan kostum tarian ini. Pemindahan objek dalam bentuk karya tari dilakukan secara abstraksi dan disusun secara acak, disesuaikan dengan komposisi tari. Tari Gulma Penida ditarikan oleh dua orang penari laki- laki dan dua orang penari perempuan, menampilkan suasana sedih diawal karena kondisi yang kurang baik sampai suasana riang setelah panen melimpah. Tarian ini merupakan tarian kreasi untuk memperkaya jenis-jenis tarian bali yang sudah ada sebelumnya.

\section{UCAPAN TERIMA KASIH}

Tulisan ini merupakan hasil penelitian kolaborasi seni antara Institut Seni Budaya Indonesia Bandung dengan Institut Seni Indonesia Denpasar. Penelitian didanai oleh riset mandatori ISBI Bandung sebagai koordinator dengan sumber dana dari Ristek-Brin dan LPDP Tahun 2020/2021. Terima kasih juga disampaikan kepada LPPM ISI Denpasar dan LPPM ISBI Bandung atas segala dukungannya. Secara takjim ucapan terima kasih juga disampaikan kepada masyarakat Nusa Penida dan para nelayan rumput laut, penenun kain rangrang, narasumber dalam FGD, serta para pendukung yang telah turut dalam memberikan kelancaran dalam proses penelitian ini.

\section{DAFTAR RUJUKAN}

Budiarsa, I. W. (2020). Penciptaan Karya Seni Tari Baris Gede Gentorag. Kalangwan : Jurnal Seni Pertunjukan, 6(2), 84-94. Retrieved from https://jurnal.isidps.ac.id/index.php/kalangwan/article/view/1224

Damayanti, I. A. K. W., Wijaya, I. N., \& Kanca, I. N. K. (2017). Strategi pengembangan Pulau Nusa Penida sebagai kawasan pariwisata yang berkelanjutan. Soshum: Jurnal Sosial dan Humaniora, 5(2), 136.

Hadi, Y. Sumandiyo. (1990). Mencipta Lewat Tari. Yogyakarta: Institut Seni Indonesia.

Indrawan, A. A. G., Sariada I. K., \& Arshiniwati N. M. (2021). Bentuk Tari Renteng di Dusun Saren I, Nusa Penida, Klungkung. Mudra Jurnal Seni Budaya, 36(1), 46-54. https://doi.org/10.31091/mudra.v36i1.1129

Kemendikbud Dirjen Kebudayaan. 2015. Tarian Sakral "Baris Jangkang". https://kebudayaan.kemdikbud.go.id/ bpnbbali/tarian-sakral-baris-jangkang/ (diakses 12 Januari 2021).

Moenandir, J. (2010). Ilmu gulma. Universitas Brawijaya Press.

Pradnyana, I., \& Nugroho, S. (2019). Upaya Revitalisasi Pertanian Rumput Laut Dalam Praktik Pariwisata Di Desa Lembongan, Kabupaten Klungkung. Jurnal Destinasi Pariwisata, 7(2), 352-363.

Pramana, I. G. E. B. (2014). Tari Gandrung Di Desa Batukandik, Nusa Penida, Klungkung, Bali (Sebagai Media Belajar Sejarah Kebudayaan). Widya Winayata: 
Jurnal Pendidikan Sejarah, 2(1).

Priono, B. (2016). Budidaya rumput laut dalam upaya peningkatan Industrialisasi perikanan. Media Akuakultur, 8(1), 1-8.

Sukerti, N. K., Pratam, N. W. C. A., \& Sukamdi, Y. (2016). IbM Industri Rangrang Di Desa Karang Ampel Nusa Penida. Prosiding Semnas Hasil Pengabdian Masyarakat.

Yusril. (2018). Konsep Garapan Dan Kreativitas Seni Teater "Rumah Dalam Diri". Mudra Jurnal Seni Budaya, 33(1), 104-113. https://doi.org/10.31091/mudra.v33i1.315 